\title{
Incorporating episodicity into estimates of Critical Loads for juvenile salmonids in Scottish streams
}

\author{
E.E. Bridcut, J. McNish and R. Harriman
}

FRS-Freshwater Laboratory, Pitlochry, Perthshire, Scotland, PH16 5LB, UK

Email for corresponding author: bridcute@marlab.ac.uk

\begin{abstract}
Critical Load (CL) methodology is currently used throughout Europe to assess the risks of ecological damage due to sulphur and nitrogen emissions. Critical acid neutralising capacity $\left(\mathrm{ANC}_{\mathrm{CRTT}}\right)$ is used in $\mathrm{CL}$ estimates for freshwater systems as a surrogate for biological damage. Although UK CL maps presently use an ANC value of $0 \mu \mathrm{eq} 1^{-1}$, this value has been based largely on Norwegian lake studies, in which brown trout is chosen as a representative indicator organism. In this study, an ANC value specific for brown trout in Scottish streams was determined and issues were addressed such as salmon and trout sensitivity in streams, episodicity, afforestation and complicating factors such as dissolved organic carbon (DOC) and labile aluminium (Al-L). Catchments with significant forest cover were selected to provide fishless sites and to provide catchment comparisons in unpolluted areas. Chemical factors were the primary determinant with land use a secondary determinant of the distribution of salmonid populations at the twenty-six study sites. ANC explained more variance in brown trout density than $\mathrm{pH}$. The most significant index of episodicity was percent of time spent below an ANC of $0 \mu$ eql ${ }^{-1}$. An $\mathrm{ANC}_{\mathrm{CRIT}} \mathrm{value}$ of $39 \mu \mathrm{eq}^{-1}$ was obtained based on a $50 \%$ probability of brown trout occurrence. The use of this revised $\mathrm{ANC}_{\mathrm{CRIT}}$ value in the CL equation improved the relationship between trout status and exceedance of CLs. Uncertainties associated with variations in Al-L at any fixed $\mathrm{ANC}_{\mathrm{CRIT}}$, particularly within forested catchments, and the role of DOC in modifying the toxicity of Al-L are discussed.
\end{abstract}

Keywords: Critical Load, Critical acid neutralising capacity, brown trout, episodes, streams

\section{Introduction}

During the past decade, the concept of Critical Loads (CL) has been developed to assess the sensitivity of surface waters to anthropogenic sulphur $(\mathrm{S})$ and nitrogen $(\mathrm{N})$ deposition and develop emission control strategies throughout Europe. CLs for acidic deposition indicate the maximum sustainable level of acidic input to a system that will not harm target organisms in the long term (Nilsson and Grennfelt, 1988). Freshwater CL maps, based on the Steady-State Water Chemistry (SSWC) model, have been used in negotiations for sulphur, (and more recently, nitrogen), emission reduction strategies on a European scale.

In the SSWC model, Critical Acid Neutralising Capacity $\left(\mathrm{ANC}_{\mathrm{CRIT}}\right)$ is used as a surrogate for biological damage (Harriman and Christie, 1993). Brown trout (Salmo trutta L.) has frequently been used as a representative indicator organism due to its ubiquitous distribution throughout Europe. Lien et al. (1992) suggested an $\mathrm{ANC}_{\text {CRIT }}$ value of $0 \mu \mathrm{eql}^{-1}$ based on a $50 \%$ probability of occurrence of brown trout populations in Norwegian lakes. For precautionary purposes, they further proposed $\mathrm{ANC}_{\mathrm{CRIT}}$ values of $20 \mu \mathrm{eq} \mathrm{l}^{-1}$ and $50 \mu \mathrm{eq}^{-1}$ to provide a $90 \%$ and $100 \%$ probability of occurrence of brown trout respectively.

Unfortunately, such surveys have not been attempted in Scotland and differences in the chemical properties of Scottish waters (notably dissolved organic carbon (DOC) and labile aluminium (Al-L)), compared to their Norwegian counterparts (Henriksen et al., 1998) may mean that these $\mathrm{ANC}_{\mathrm{CRIT}}$ values are not directly applicable to Scottish lochs. Furthermore, these derived $\mathrm{ANC}_{\mathrm{CRIT}}$ values are applicable to lake dwelling brown trout populations, which are older and less sensitive than juvenile trout inhabiting upland streams.

Salmonid populations are most vulnerable to acidification during egg development or the transition to exogenous feeding (Peterson et al., 1980; Lacroix et al., 1985), especially in streams draining upland catchments which receive significant inputs of acidic deposition and are subject 
to more intense episodic chemistry than in lakes. Such acidic episodes can have detrimental affects on fish, subjecting them to toxic concentrations of acidity and aluminium.

UK CL maps are currently based on chemical data from lakes, using an $\mathrm{ANC}_{\mathrm{CRIT}}$ value of $0 \mu \mathrm{eql}^{-1}$. However, because of the greater sensitivity of brown trout juveniles in streams compared to lakes and encountering more frequent acid episodes, a higher $\mathrm{ANC}_{\mathrm{CRIT}}$ value may be more appropriate, especially if a higher probability of occurrence is deemed necessary for conservation and sustainability requirements.

Land use can also exacerbate the effects of acidification on fish (Harriman and Morrison, 1982), particularly coniferous forest plantations, which are established mainly in upland catchments. By increasing the scavenging of atmospheric pollutants, mature forests can increase acidity and aluminium concentrations in drainage streams. Through growth requirements, trees can also increase soil acidification via base cation uptake and the slow decay rate of conifer litter results in the accumulation of large quantities of humus, rich in organic acids (Friberg et al., 1998; Morrison, 1998).

Salmonid populations are affected by factors other than those related to acidification. Riparian vegetation is beneficial to salmonid populations providing a form of cover, shade and a valuable food source (Bridcut, 2000). Habitat features such as flow, depth, substrate and cover, are all influential on the distribution of salmonid populations (Heggenes et al., 1999). These factors were also included in the initial analysis.

The aims of this study are firstly to establish the importance of the chemical effects on lotic salmonid populations and secondly, to identify the key indicators of episodic acidification and determine any significant correlation between these indicator variables and salmonid densities. Thirdly, to establish a mean $\mathrm{ANC}_{\text {CRIT }}$ value for trout, incorporating indices of episodicity, which can be used in the CL equations. This is especially important in such vulnerable locations as afforested sites and which therefore form an important component in this study.

\section{Study sites}

Twenty-six chemical and fish sampling sites were selected in five different catchments around Scotland to reflect a range of geology, $\mathrm{S}$ and $\mathrm{N}$ deposition and land use particularly including coniferous forest (Fig. 1 and Table 1). Six streams were chosen in each catchment (with the exception of the Bladnoch catchment, where two sites were selected) to cover a wide range of ANC values within and between each catchment and region. Variation in instream habitat features was kept to a minimum, selected sites being

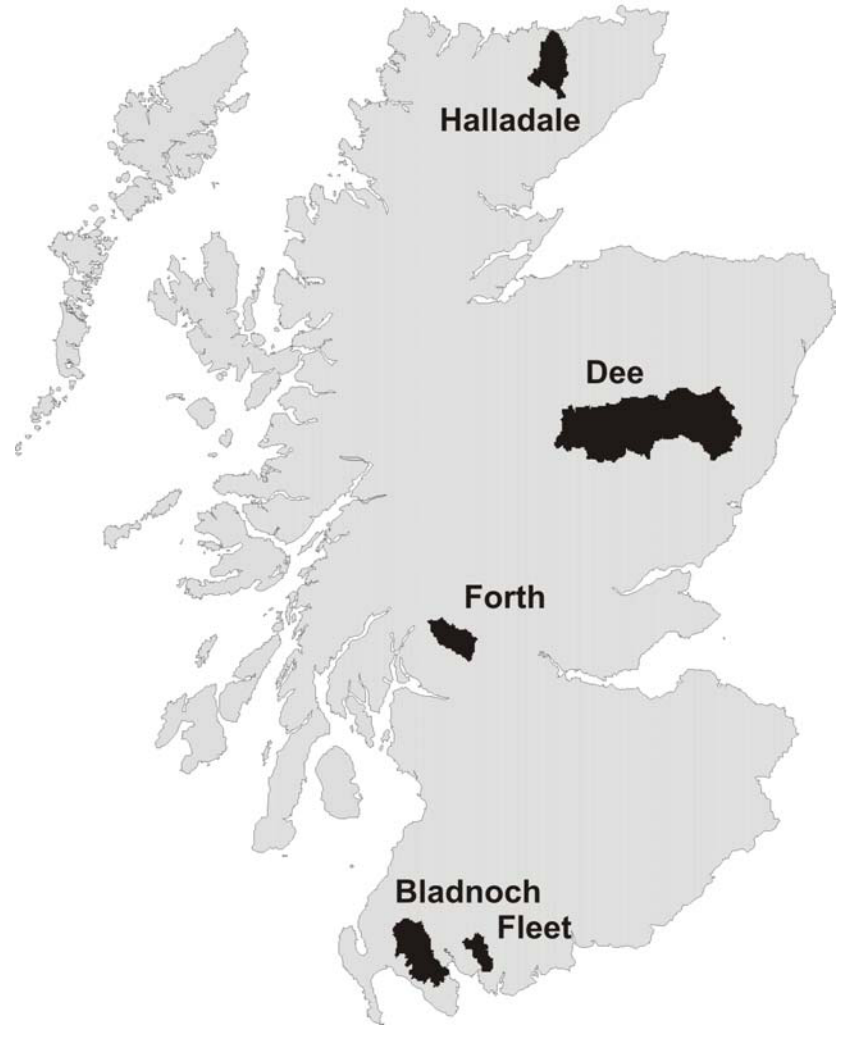

Fig. 1. Study catchments

approximately 2-10 $\mathrm{m}$ in width, with both pool and riffle habitats, similar substrate composition consisting mostly of boulder, cobble and pebble content with overhanging but not dense vegetation. Only the Polbae stream in the Bladnoch catchment and the Greendams stream in the Dee catchment had records of restocking with juvenile Atlantic salmon ( $S$. salar L.). All sites were accessible by salmon and brown trout with the exception of Burns 2 and 6 and Manhole in the River Forth catchment, where waterfalls in the lower waters inhibit the passage of spawning salmon (P. Collen pers. comm.). Salmon are not known to access the upper waters of Allt an t-Sionnach in the Dee catchment (A. Hudson, pers. comm.).

\section{Materials and methods}

Fish sampling was carried out in summer (July and August) and autumn (September and October) 1998 at each site. On each fish sampling occasion, stop nets were used to enclose an area of approximately $100 \mathrm{~m}^{2}$ in the selected stream. Fish were captured using $400 \mathrm{~V}$ smooth D.C. electrofishing apparatus by fishing the enclosed stretch in an upstream direction three times. Captured fish were held in a perforated box situated in the stream. All fish were anaesthetised with 
Table 1. Location, mean $\mathrm{pH}, \mathrm{ANC}\left(\mu \mathrm{eq} \mathrm{1}^{-1}\right)$, AL-L $\left(\mu \mathrm{eq} \mathrm{1}^{-1}\right)$ and dominant land-use at the 26 study sites across Scotland.

\begin{tabular}{|c|c|c|c|c|c|c|}
\hline Study site & Grid ref. & Code & $p H$ & $A N C$ & $A L-L$ & Land-use \\
\hline \multicolumn{7}{|l|}{ FLEET } \\
\hline Barlay & NX 599579 & BYF & 7.7 & 1002 & 10 & Pasture \\
\hline Castramont & NX 586616 & CTF & 6.2 & 323 & 5 & Deciduous \\
\hline Carrouch & NX 547665 & $\mathrm{CHF}$ & 5.0 & 28 & 35 & Coniferous \\
\hline Cardoon & NX 527648 & $\mathrm{CDF}$ & 5.0 & 74 & 14 & Moorland \\
\hline Benmeal & NX 559658 & BLF & 4.5 & 38 & 66 & Coniferous \\
\hline Craiglowrie & NX 553670 & CEF & 4.5 & 22 & 108 & Coniferous \\
\hline \multicolumn{7}{|l|}{ BLADNOCH } \\
\hline Polbae & NX 263728 & POB & 5.4 & 199 & 4 & Coniferous \\
\hline Beoch & NX 314715 & BHB & 6.1 & 146 & 5 & Deciduous \\
\hline \multicolumn{7}{|l|}{ DEE-ABERDEENSHIRE } \\
\hline Allt Dhaidh Mor & NN 964878 & DMD & 5.7 & 41 & 7 & Moorland \\
\hline Allt Dhaidh Beag & NN 979877 & DBD & 5.7 & 57 & 7 & Moorland \\
\hline Allt an t-Sionnach & NO 087861 & SHD & 7.1 & 228 & 5 & Moorland \\
\hline Allt an t-Slugain & NO 149941 & SND & 7.0 & 152 & 5 & Moorland \\
\hline Pollagach & NO 414960 & PHD & 7.2 & 331 & 6 & Deciduous \\
\hline Greendams & NO 648900 & GMD & 6.0 & 73 & 8 & Coniferous \\
\hline \multicolumn{7}{|l|}{ HALLADALE } \\
\hline Achridigill & NC 887628 & $\mathrm{ACH}$ & 5.6 & 161 & 3 & Moorland \\
\hline Forsinain & NC 905485 & $\mathrm{FOH}$ & 5.7 & 207 & 3 & Moorland \\
\hline Ewe & NC 893450 & EWH & 5.8 & 236 & 2 & Moorland \\
\hline Bealach East & NC 905410 & $\mathrm{BEH}$ & 5.2 & 62 & 14 & Moorland \\
\hline Bealach West & NC 904410 & BWH & 5.5 & 155 & 11 & Moorland \\
\hline R.Halladale at the gorge & NC 913412 & $\mathrm{HGH}$ & 5.5 & 151 & 8 & Moorland \\
\hline \multicolumn{7}{|l|}{ FORTH } \\
\hline Green Burn & NS 507945 & GBF & 5.8 & 122 & 7 & Coniferous \\
\hline Manhole & NS 484949 & MEF & 6.5 & 204 & 8 & Coniferous \\
\hline Burn 6 & NS 436986 & $\mathrm{~B} 6 \mathrm{~F}$ & 6.1 & 69 & 6 & Coniferous \\
\hline Burn 2 & NN 387043 & $\mathrm{~B} 2 \mathrm{~F}$ & 5.2 & 35 & 17 & Pasture \\
\hline Burn 7 & NS 448984 & $\mathrm{~B} 7 \mathrm{~F}$ & 4.8 & 17 & 95 & Coniferous \\
\hline Burn 11 & NS 471985 & $\mathrm{~B} 11 \mathrm{~F}$ & 4.5 & 55 & 61 & Coniferous \\
\hline
\end{tabular}

benzocaine, then measured and weighed. Scales were removed for age analysis from a sub-sample of fish. The fish were then transferred to a recovery bucket of fresh water and later returned to the centre of each site. Age analysis was carried out using a combination of both lengthfrequency distributions and scale reading.

On each fish sampling occasion, a detailed in-stream habitat survey was carried out. After electrofishing, the enclosed stretch of stream was divided into five subsections. The following variables were measured within each subsection: wet width; water depth $(1 / 4,1 / 2$ and $3 / 4$ across the width of the stream); substrate type, based on a modified Wentworth scale $(\mathrm{cm})$, as used in similar studies (Bain et al., 1985): bedrock, boulders $>25.6$, cobbles 6.4-25.6, pebbles 1.6-6.4, gravel 0.2--1.6, coarse sand 0.01-0.2, silt $<0.01$, clay/peat and obscured substrate; flow types (torrent, riffle, run, deep/shallow glide, deep/shallow pool, still margins); the percentage of overhanging vegetation and the proportion of vegetation types (deciduous, coniferous, shrub/gorse/heather, herbaceous) that contributed to this overhang; percentage of aquatic vegetation and the proportion of vegetation types (algae, lichen/moss/liverwort, higher plants) that contributed to the total amount of aquatic vegetation; percentage of instream habitat providing fish cover and the proportion of defined cover: substrate, branches, draped vegetation, aquatic vegetation, undercut 
banks, water.

Geographical location features for each site (longitude, latitude, altitude, distance from source, catchment area, direction in which the catchment is facing) were determined from ordnance survey maps 1:25,000 and Geographical Information Systems (GIS). The principal riparian land use, up to $200 \mathrm{~m}$ upstream, and the riparian corridor, up to $50 \mathrm{~m}$ from both banks, was recorded on each fish sampling occasion.

Water samples were collected at all sites on at least a monthly basis covering a wide range of flows. Samples were also taken on each biological sampling occasion. After filtering through a $0.45 \mu \mathrm{m}$ polycarbonate membrane filter, the water samples were analysed for major anions and cations ( $\mathrm{Na}, \mathrm{K}, \mathrm{Ca}, \mathrm{Mg}, \mathrm{SO}_{4}, \mathrm{Cl}, \mathrm{NO}_{3}$ ) using a DX100 Dionex (C) ion Chromatograph. Alkalinity and $\mathrm{pH}$ were determined using a radiometer auto-titration system with glass reference electrodes and dual end point titration. Aluminium was determined as both labile (ionic) and nonlabile (organic) species by ion exchange followed by colourimetric determination by the pyrocatechol violet technique. Dissolved organic content was determined using an organic carbon analyser by oxidation of all carbon forms to $\mathrm{CO}_{2}$. Further details on the chemical analysis can be found in Harriman et al. (1987, 1990a).

\section{Data analysis}

ANC was calculated according to Cantrell et al. (1990), where:

$$
\operatorname{ANC}\left(\mu \mathrm{eql}^{-1}\right)=\mathrm{ALK}+(\mathrm{DOC} \times 5)
$$

ALK is the equivalence alkalinity ( $\mu$ eq $1^{-1}$ ) based on a dual end-point titration in the $\mathrm{pH}$ range of 4.5 to 4.2 and DOC is the dissolved organic carbon content $\left(\mathrm{mg} \mathrm{l}^{-1}\right)$ (Harriman and Taylor, 1999). Using the SSWC model, CL values were calculated according to the following equation:

$$
\mathrm{CL}=\left([\mathrm{BC}]_{\mathrm{o}}^{*}-\left[\mathrm{ANC}_{\mathrm{CRIT}}\right] \cdot \mathrm{Q}-[\mathrm{BC}]_{\mathrm{d}}^{*} \cdot \mathrm{R},\right.
$$

where: * indicates non-marine component; $[\mathrm{BC}]_{\mathrm{o}}$ is the excess base cation concentration prior to acidiification; $\mathrm{Q}$ is the runoff; $[\mathrm{BC}]_{\mathrm{d}}$ is the non-marine base cation deposition. Exceedance of $\mathrm{CL}\left(\mathrm{CL}_{\mathrm{EX}}\right)$ was calculated according to Harriman and Christie (1993), where:

$$
\mathrm{CL}_{\mathrm{EX}}=\mathrm{CL}-\mathrm{S} \text { deposition, }
$$

Sulphur deposition data were taken from the official UK CL 1995-1997 deposition dataset. Daily mean flow records for the selected catchments were provided by the Scottish Environmental Protection Agency (SEPA) from which $\mathrm{pH}-$ flow relationships were constructed using parametric linear (LM) and nonparametric generalised additive (GLM) models. Similarly, using LM and GLM, ANC was predicted from $\mathrm{pH}$. Flow, $\mathrm{pH}$ and $\mathrm{ANC}$ duration curves were constructed for each site from which the percent of time spent below certain $\mathrm{pH}$ and ANC thresholds were estimated. The thresholds used were $\mathrm{pH} \leq \mu 5.0,5.5,6.0$ and $\mathrm{ANC} \leq 0$, 20 and $50 \mu \mathrm{eq} \mathrm{l}^{-1}$, the percent of time spent below these thresholds provided a measurement of acid episodicity. The use of modal values as indicators of base-flow chemistry was proposed by Brewin et al. (1998) who further suggested that minimum values could indicate true episodic fluctuations relative to, but independent of base-flow modal values. These authors also used modal $\mathrm{pH}$-minimum $\mathrm{pH}$ as an index of episodicity, which was calculated for all the present study sites; similar indices were calculated for $\mathrm{pH}$ converted to hydrogen ion concentration (to produce a nonlogarithmic index) and ANC.

Densities of fish for each age class were estimated by the Zippin method (Zippin, 1956). To examine site variation in the occurrence of salmonids, salmon and trout Zippin densities at each site, where salmonids were captured, were classified using two-way indicator species analysis (TWINSPAN; Hill,1979). This method of classification arranges the sites into a hierarchy based on the densities of the different age classes of the two salmonid species. Indicator species were identified. Pseudo-species cut levels of 0,10 and 100 were used and the classification programme was terminated at level two. TWINSPAN classification was carried out separately for summer and autumn salmonid densities so as to avoid any seasonal effects.

Spearman rank correlations were performed between the density of each salmonid age class in each season and the mean values of instream habitat, geographical location and chemistry parameters.

Because over 70 variables were used in this analysis, three separate principal components analyses (PCA) were carried out to reduce the instream habitat, geographical location and chemistry data set to a smaller number of components. The first two PCA axes accounted for most of the variation (30-69\%) (see Table 2). The PCA routine in CANOCO was performed using $\log (\mathrm{x}+1)$ transformed environmental data, with centring and standardisation by species.

Forward stepwise multiple regressions were conducted on salmonid densities in summer and autumn using PCA axes one and two from the instream habitat, geographical location and chemistry data as the independent variables. All data except PCA axes were $\log _{10}(x+1)$ transformed to improve normality. Outliers in the data $(\mathrm{N} \leq 2)$, when present, 
Table 2. Major patterns in geographical location, chemistry and habitat data, as shown by PCA. Only variables significantly correlated with each of the two PCA axes are presented in order of their correlation coefficient, the direction of each relationship is indicated by + - sign.

\begin{tabular}{lllll}
\hline GEOGRAPHICAL & GEOGRAPHICAL & CHEMISTRY & PCA 1 & CHEMISTRY PCA 2 \\
LOCATION PCA 1 & LOCATION PCA 2 & & \\
\hline
\end{tabular}

\begin{tabular}{|c|c|c|c|}
\hline Eigenvalue $=0.22$ & Eigenvalue $=0.17$ & Eigenvalue $=0.45$ & Eigenvalue $=0.24$ \\
\hline Catchment area - & Moorland land use - & $\mathrm{ANC}+$ & $\mathrm{Cl}-$ \\
\hline Coniferous land use + & Riparian moorland - & Calcium + & $\mathrm{DOC}-$ \\
\hline Riparian moorland - & Latitude - & Alkalinity + & $\mathrm{Na}-$ \\
\hline Distance from source - & Site elevation -- & $\mathrm{Mg}+$ & Total N- \\
\hline Riparian buff. conifers + & Riparian herbaceous + & Labile $\mathrm{Al}-$ & $\mathrm{pH}+$ \\
\hline$\%$ aspect west - & Deciduous land use + & $\mathrm{Na}+$ & $\mathrm{K}-$ \\
\hline Moorland land use - & $\%$ aspect south + & $\mathrm{K}+$ & \\
\hline$\%$ aspect south - & Longitude + & $\mathrm{Cl}+$ & \\
\hline$\%$ aspect east + & Riparian buff. deciduous + & & \\
\hline
\end{tabular}

\begin{tabular}{|c|c|c|c|}
\hline SUMMER HABITAT PCA 1 & SUMMER HABITAT PCA 2 & AUTUMN HABITAT PCA 1 & AUTUMN HABITAT PCA 2 \\
\hline Eigenvalue $=0.16$ & Eigenvalue $=0.14$ & Eigenvalue $=0.19$ & Eigenvalue $=0.18$ \\
\hline Boulders - & Riffle - & Boulder - & Depth + \\
\hline Substrate for fish cover -- & Aquatic veg. for fish cover + & Substrate for fish cover - & Deep glide + \\
\hline Overhanging vegetation + & Higher plants + & Peat + & Cobble - \\
\hline Width -Shallow pool + & Algae - & Silt + & Shallow pool - \\
\hline Deep pool + & Silt + & Pebble + & Aquatic veg. for fish cover + \\
\hline Draped vegetation + & Shallow glide + & Draped vegetation + & Water for fish cover + \\
\hline Undercut banks + & Margins + & Overhanging vegetation + & Aquatic vegetation + \\
\hline Torrent - & Shrub/gorse/heather overhang + & Riffle - & Fish cover + \\
\hline Run - & Fish cover - & Run - & \\
\hline Water for fish cover - & Coniferous overhang - & Undercut banks + & \\
\hline Pebble + & Deciduous overhang - & Obscured substrate - & \\
\hline Depth - & Moss + & Torrent - & \\
\hline Herbaceous overhang - & Obscured substrate + & Flow index - & \\
\hline Deciduous overhang + & Aquatic vegetation + & Fish cover - & \\
\hline Branches for fish cover + & & Width - & \\
\hline Gravel + & & Aquatic vegetation - & \\
\hline & & Herbaceous overhang - & \\
\hline
\end{tabular}

were removed before data analysis was carried out. Explanatory variables were entered in the regression model only if the variable was significant at $\mathrm{P}<0.15$ (Gibson et al., 1993) and appear in the regression equation (Table 3) in order of their relative contribution in the prediction of the dependent variable.

Linear regressions were carried out to compare the relationship between $\mathrm{pH}$ and $\mathrm{ANC}$ with salmonid density in addition to determining whether the mean, minimum or median $\mathrm{pH} / \mathrm{ANC}$ value was most influential on salmonid survival.

A stepwise method was used to link the episodic variables to an $\mathrm{ANC}_{\mathrm{CRIT}}$ value as follows:

STEP 1 Determine which episodic variable produces the best linear relationship with salmonid density; 
Table 3. Significant stepwise multiple regression equations for salmon and trout density $\left(\log _{10} \operatorname{nos} 100 \mathrm{~m}^{-2}\right)$ in summer and autumn.

\begin{tabular}{|c|c|c|c|c|}
\hline Density & Equation & $N$ & $R^{2}$ model & $R^{2} a d j$ \\
\hline \multicolumn{5}{|l|}{ TROUT SUMMER } \\
\hline Total trout & $1.09+0.44($ PCA1CHEM)-0.19(PCA2LOC)+0.17(PCA2CHEM) & 26 & 0.53 & 0.47 \\
\hline $0+$ trout & $0.80+0.51$ (PCA1CHEM)-0.26(PCA2LOC) & 26 & 0.55 & 0.47 \\
\hline \multicolumn{5}{|c|}{ Trout AUTUMn } \\
\hline Total trout & $1.24+0.21($ PCA1CHEM $)+0.11($ PCA1HAB $)$ & 22 & 0.42 & 0.32 \\
\hline $0+$ trout & $1.01+0.36($ PCA1CHEM $)+0.17($ PCA1LOC $)+0.12($ PCA2CHEM $)$ & 21 & 0.59 & 0.49 \\
\hline $1+$ trout & $0.72+0.17$ (PCA1CHEM) & 21 & 0.22 & 0.18 \\
\hline \multicolumn{5}{|c|}{ SALMON SUMMER } \\
\hline $0+$ salmon & $0.47+0.30($ PCA1CHEM $)+0.42($ PCA2HAB $)+0.21($ PCA2LOC $)$ & 22 & 0.65 & 0.57 \\
\hline $1+$ salmon & $0.55-0.29(\mathrm{PCA} 1 \mathrm{LOC})+0.22(\mathrm{PCA} 1 \mathrm{CHEM})+0.20(\mathrm{PCA} 2 \mathrm{HAB})$ & 22 & 0.73 & 0.66 \\
\hline $2+$ salmon & 0.11-0.17(PCA1LOC)-0.07(PCA1CHEM) & 20 & 0.71 & 0.68 \\
\hline \multicolumn{5}{|c|}{ SALMON AUTUMN } \\
\hline Total salmon & $0.61+0.27$ (PCA1CHEM) -0.59 (PCA1LOC) +0.20 (PCA2LOC) -0.18 (PCA2CHEM) & 16 & 0.94 & 0.92 \\
\hline $0+$ salmon & $0.58+0.38$ (PCA1CHEM)-0.31(PCA1HAB) & 18 & 0.49 & 0.34 \\
\hline $1+$ salmon & $0.42+0.32$ (PCA1CHEM)-0.41(PCA1LOC) & 16 & 0.90 & 0.87 \\
\hline $2+$ salmon & $0.15-0.14($ PCA 1 LOC $)+0.16($ PCA1CHEM $)-0.07($ PCA2HAB $)$ & 18 & 0.71 & 0.63 \\
\hline
\end{tabular}

STEP 2 Use logistic regressions to determine the value of the chosen episodic variable equivalent to a selected probability of occurrence for salmonids;

STEP 3 Establish regression relationships between the chosen episodic variable and mean dip ANC $\left(\mathrm{ANC}_{\mathrm{D}}\right)$ (this value is relatively easy to determine from water sample analysis);

STEP 4 Use the relationships from steps 2) and 3) to find the mean dip $\mathrm{ANC}\left(\mathrm{ANC}_{\mathrm{EP}}\right)$ equivalent to the value of the chosen episodic variable, at a given probability of occurrence of salmonids. If a $50 \%$ probability was selected as an appropriate criterion for Critical Load mapping, then $\mathrm{ANC}_{\mathrm{EP}}$ at that probability would become $\mathrm{ANC}_{\text {CRIT }}$.

\section{Results}

Salmon and trout were absent from the following sites: Benmeal; Craiglowrie; Burn 7 and Burn 11, where mean $\mathrm{pH}$ and $\mathrm{ANC}$ values ranged from 4.5 to 4.8 and from 17 to $55 \mu$ eq $1^{-1}$ respectively (Table 1 ). Trout were present in the remaining sites, however, no salmon were captured in the Forth catchment or in the Bealach East stream in the Halladale catchment. European eel (Anguilla anguilla L.) was present in all catchments with the exception of the Forth. Brook lamprey (Lampetra planeri (Bloch)) was found at Greendams and both three-spinned stickleback
(Gasterostrus aculeatus L.) and stone loach (Noemacheilus barbatulus (L.)) were present in the Barlay stream.

Salmon tended to avoid pool habitats with large amounts of overhanging vegetation, preferring substrate, e.g. boulders rather than pebble and cobble, and aquatic vegetation as a means of cover. Overhanging vegetation, a possible source of cover and food sources, was the most influential habitat feature for trout density. However, regression models, using the PCA axes (Table 2), revealed chemical factors, namely the acid buffering variables, were the most positive predictors of $0+$ and $1+$ salmon and trout density at the study sites (Table 3). Similarly. the TWINSPAN classification arranged the 22 study sites, where salmonid populations were captured, into two groups strongly related to ANC, $\mathrm{pH}$ and aluminium (Fig. 2). Geographical location variables, predominantly the presence of coniferous land use and absence of moorland (Table 2), were the most negative predictors of salmonid densities particularly the older aged salmon (Table 3). ANC was a better explanatory variable than $\mathrm{pH}$ of salmonid densities. Minimum ANC, as determined from dip water samples, was the best explanatory variable for trout density $\left(\mathrm{R}^{2}\right.$ values of 0.49-0.57), while median ANC was a better explanatory variable for salmon density ( $\mathrm{R}^{2}$ values of $0.29-0.61$ ).

The significant linear relationships between the predicted $\mathrm{pH}$ and ANC episodic indices and salmonid densities are presented in Table $4 \mathrm{a}$ and $\mathrm{b}$. Generally, the relationships 


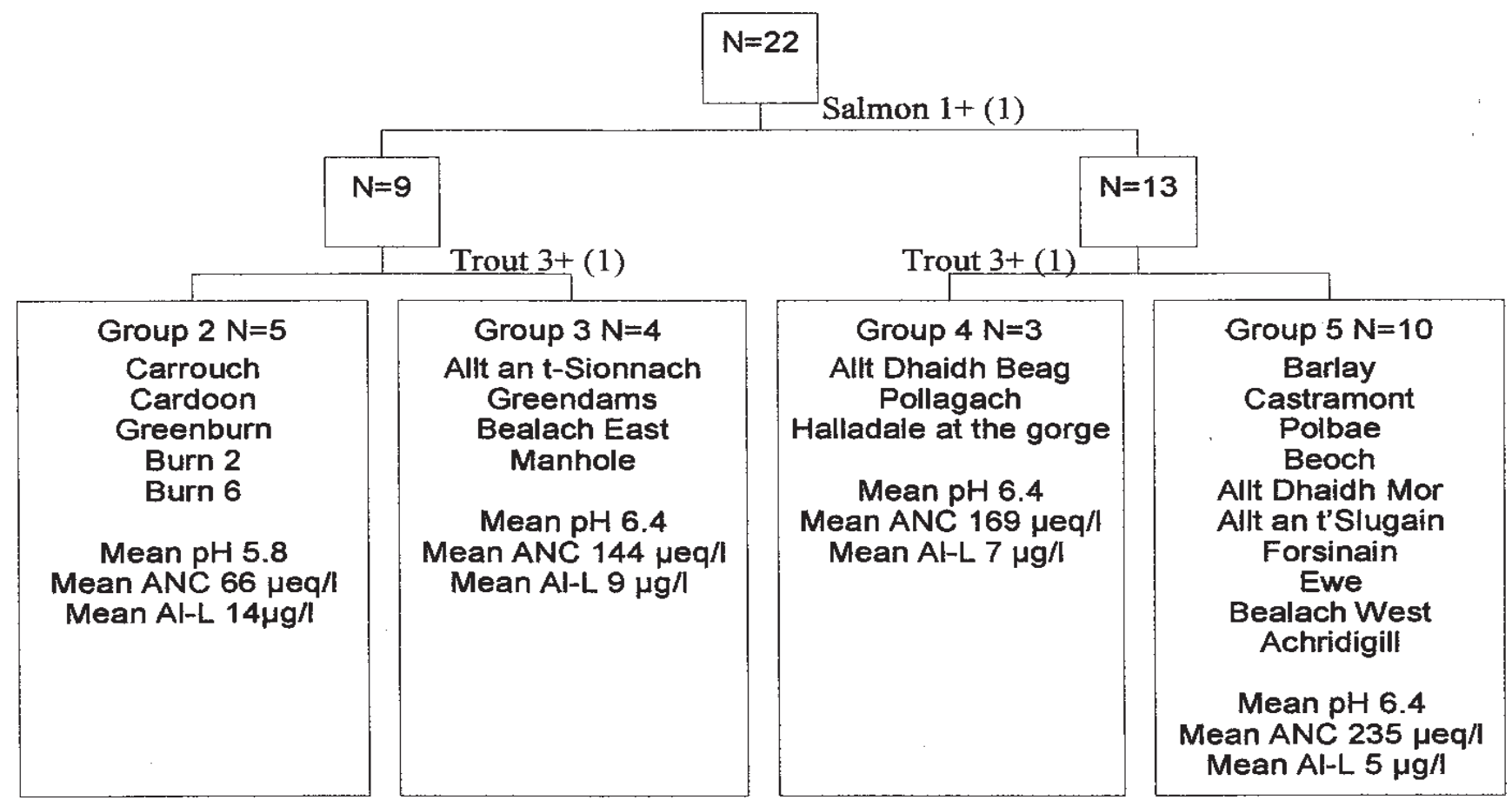

Fig. 2(a). TWINSPAN classification of salmonid densities captured in summer and the indicator species (minimum score required for classification is indicated in brackets)

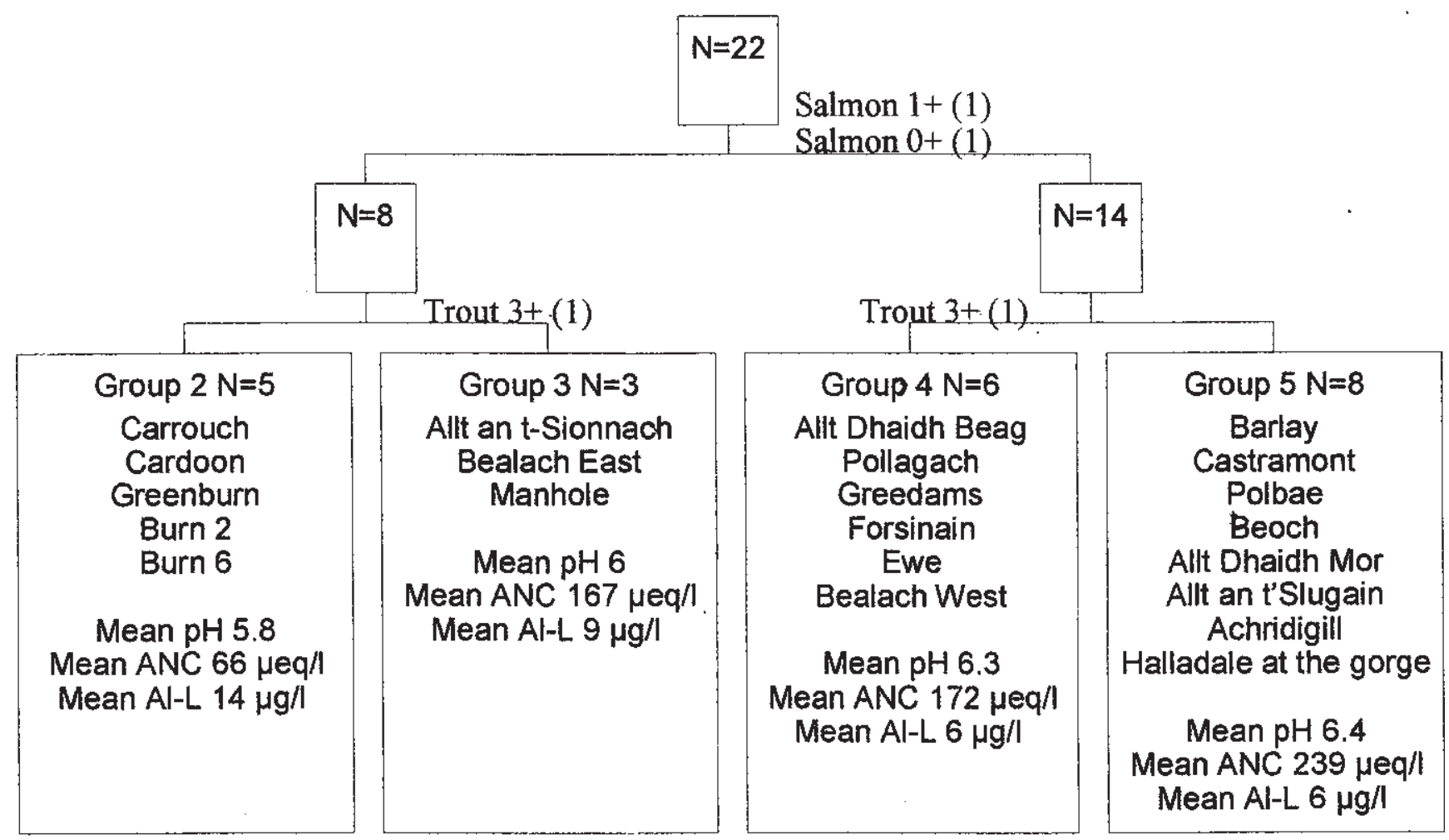


Table $4 a$. Linear regressions between the predicted $\mathrm{pH}$ and ANC ( $\left.\mu \mathrm{eq} \mathrm{l}^{-1}\right)$ values and salmonid density in summer (all variables are logged except $\mathrm{pH}$, significant relationships are in bold, $+/-$ indicates the slope of the line).

\begin{tabular}{|c|c|c|c|c|c|c|c|c|}
\hline & \multicolumn{2}{|c|}{$0+$ Trout } & \multicolumn{2}{|c|}{ Total Trout } & \multicolumn{2}{|c|}{$0+$ Salmon } & \multicolumn{2}{|c|}{ Total Salmon } \\
\hline & $R^{2}$ & $P$ & $R^{2}$ & $P$ & $R^{2}$ & $P$ & $R^{2}$ & $P$ \\
\hline$\%$ time at $\mathrm{pH}<5.0$ & -0.44 & 0.001 & -0.60 & 0.001 & -0.11 & 0.13 & -0.28 & 0.01 \\
\hline$\%$ time at $\mathrm{pH}<5.5$ & -0.35 & 0.001 & -0.45 & 0.001 & -0.10 & 0.16 & -0.28 & 0.01 \\
\hline$\%$ time at $\mathrm{pH}<6.0$ & -0.28 & 0.006 & -0.35 & 0.001 & -0.04 & 0.40 & -0.20 & 0.04 \\
\hline$\%$ time at $\mathrm{ANC}<0$ & -0.37 & 0.001 & -0.53 & 0.001 & -0.12 & 0.12 & -0.24 & 0.02 \\
\hline$\%$ time at $\mathrm{ANC}<20$ & -0.48 & 0.001 & -0.52 & 0.001 & -0.29 & 0.01 & -0.38 & 0.002 \\
\hline$\%$ time at $\mathrm{ANC}<50$ & -0.41 & 0.001 & -0.38 & 0.001 & -0.34 & 0.004 & -0.46 & 0.001 \\
\hline Modal pH & +0.30 & 0.004 & +0.41 & 0.001 & +0.15 & 0.08 & +0.32 & 0.01 \\
\hline Modal ANC & +0.31 & 0.003 & +0.33 & 0.002 & +0.20 & 0.04 & +0.27 & 0.01 \\
\hline Mean pH & +0.42 & 0.001 & +0.53 & 0.001 & +0.10 & 0.14 & +0.28 & 0.01 \\
\hline Mean ANC & +0.38 & 0.001 & +0.38 & 0.001 & +0.30 & 0.01 & +0.38 & 0.002 \\
\hline Min $\mathrm{pH}$ & +0.39 & 0.001 & +0.44 & 0.001 & +0.04 & 0.39 & +0.16 & 0.07 \\
\hline Min ANC & +0.51 & 0.001 & +0.40 & 0.001 & +0.16 & 0.06 & +0.19 & 0.04 \\
\hline Modal-Min pH & +0.001 & 0.88 & +0.02 & 0.47 & +0.10 & 0.16 & +0.11 & 0.12 \\
\hline Modal-Min ANC & +0.11 & 0.10 & +0.13 & 0.08 & +0.14 & 0.08 & +0.20 & 0.03 \\
\hline
\end{tabular}

Table $4 b$. Linear regressions between the predicted $\mathrm{pH}$ and ANC ( $\left.\mu \mathrm{eq} \mathrm{l}^{-1}\right)$ values and salmonid density in autumn (all variables are logged except $\mathrm{pH}$, significant relationships are in bold, $+/-$ indicates the slope of the line).

\begin{tabular}{|c|c|c|c|c|c|c|c|c|}
\hline & \multicolumn{2}{|c|}{$0+$ Trout } & \multicolumn{2}{|c|}{ Total Trout } & \multicolumn{2}{|c|}{ 0+ Salmon } & \multicolumn{2}{|c|}{ Total Salmon } \\
\hline & $R^{2}$ & $P$ & $R^{2}$ & $P$ & $R^{2}$ & $P$ & $R^{2}$ & $P$ \\
\hline$\%$ time at $\mathrm{pH}<5.0$ & -0.45 & 0.001 & -0.61 & 0.001 & -0.26 & 0.01 & -0.41 & 0.001 \\
\hline$\%$ time at $\mathrm{pH}<5.5$ & -0.36 & 0.001 & -0.47 & 0.001 & -0.26 & 0.02 & -0.43 & 0.001 \\
\hline$\%$ time at $\mathrm{pH}<6.0$ & -0.30 & 0.004 & -0.37 & 0.001 & -0.19 & 0.04 & -0.38 & 0.002 \\
\hline$\%$ time at $\mathrm{ANC}<0$ & -0.48 & 0.001 & -0.69 & 0.001 & -0.18 & 0.06 & -0.28 & 0.01 \\
\hline$\%$ time at $\mathrm{ANC}<20$ & -0.43 & 0.001 & -0.50 & 0.001 & -0.43 & 0.001 & -0.52 & 0.0002 \\
\hline$\%$ time at $\mathrm{ANC}<50$ & -0.35 & 0.002 & -0.37 & 0.001 & -0.52 & 0.001 & -0.64 & 0.001 \\
\hline Modal pH & +0.41 & 0.001 & +0.55 & 0.001 & +0.23 & 0.02 & +0.44 & 0.001 \\
\hline Modal ANC & +0.32 & 0.003 & +0.41 & 0.001 & +0.22 & 0.03 & +0.41 & 0.001 \\
\hline Mean pH & +0.46 & 0.001 & +0.58 & 0.001 & +0.23 & 0.03 & +0.47 & 0.0004 \\
\hline Mean ANC & +0.37 & 0.001 & +0.43 & 0.001 & +0.33 & 0.01 & +0.57 & 0.001 \\
\hline Min $\mathrm{pH}$ & +0.37 & 0.001 & +0.46 & 0.001 & +0.10 & 0.16 & +0.30 & 0.01 \\
\hline Min ANC & +0.38 & 0.001 & +0.39 & 0.001 & +0.10 & 0.15 & +0.33 & 0.005 \\
\hline Modal-Min pH & +0.04 & 0.34 & +0.07 & 0.19 & +0.09 & 0.18 & +0.09 & 0.18 \\
\hline Modal-Min ANC & +0.15 & 0.05 & +0.20 & 0.02 & +0.15 & 0.07 & +0.30 & 0.01 \\
\hline
\end{tabular}

with the percent of time spent below ANC $0 \mu \mathrm{eq} \mathrm{l}^{-1}$ produced the greatest amount of explanation for trout density whilst the relationship with the percent of time spent below ANC $50 \mu \mathrm{eq} \mathrm{l}^{-1}$ produced the greatest degree of explanation for salmon density. The episodic indicator, percent of time below ANC $0 \mu$ eq $1^{-1}$, was therefore used as the episodic variable to determine an $\mathrm{ANC}_{\mathrm{EP}}$ value for brown trout, the indicator species, as described in steps $1-4$ above. $\mathrm{ANC}_{\mathrm{EP}}$ values were calculated for a range of probabilities of occurrence as outlined in Table 5 and varied from $74 \mu \mathrm{eq} \mathrm{1}^{-1}$, to ensure a $95 \%$ probability of trout occurrence, to $30 \mu \mathrm{eq} \mathrm{l}^{-1}$, giving a $25 \%$ probability of occurrence. A $50 \%$ probability was chosen for $\mathrm{CL}$ and $\mathrm{CL}_{\mathrm{EX}}$ calculations, which corresponded to an $\mathrm{ANC}_{\mathrm{EP}}$ value of $39 \mu \mathrm{eq} \mathrm{1}^{-1}$. Linear regressions between the percent of time below ANC $0 \mu \mathrm{eq} 1^{-1}$ and trout density explained approximately $60 \%$ of the variation $\left(\mathrm{R}^{2}\right.$ values ranging from $0.69-0.53)$. This compared with less than $50 \%$ of the variation $\left(\mathrm{R}^{2}\right.$ values ranging from $\left.0.50-0.43\right)$ being 
Table 5. Mean dip ANC values ( $\mu \mathrm{eql}^{-1}$ ) corresponding to $95,90,80,50$ and $25 \%$ probability occurrence of total trout and total salmon in summer and autumn $\left(\mathrm{ANC}_{\mathrm{EP}}=\right.$ mean dip $\mathrm{ANC}$ value derived using the episodic variable, $\%$ time $<\mathrm{ANC}$ threshold, $\mathrm{ANC}_{\mathrm{D}}=$ mean dip ANC valued derived directly from the ANC dip samples. $\mathrm{R}^{2}$ and associated $\mathrm{P}$ values (in brackets directly below) refer to the linear regression equation between the salmonid densities and \% time $<\mathrm{ANC}$ threshold or $\mathrm{ANC}_{\mathrm{D}}, \mathrm{C}^{2}$ and associated $\mathrm{P}$ values (in brackets directly below) refer to the logistic regression equation between salmonid occurrence and the $\%$ time $<\mathrm{ANC}$ threshold or $\mathrm{ANC}_{\mathrm{D}}$ )

\begin{tabular}{|c|c|c|c|c|c|c|}
\hline \multirow{4}{*}{$\%$ probability } & \multicolumn{2}{|c|}{$\begin{array}{l}\text { TOTAL TROUT IN SUMMER } \\
\text { Mean dip ANC + episodic data }\end{array}$} & \multirow{2}{*}{$\begin{array}{l}\text { Mean dip } A N C \\
A N C_{D}\end{array}$} & \multicolumn{2}{|c|}{$\begin{array}{l}\text { TOTAL TROUT IN AUTUMN } \\
\text { Mean dip ANC + episodic data }\end{array}$} & \multirow{2}{*}{$\begin{array}{l}\text { Mean dip } A N C \\
A N C_{D}\end{array}$} \\
\hline & $\%$ time $A N C \leq 0$ & $A N C_{E P}$ & & $\%$ time $A N C \leq 0$ & $A N C_{E P}$ & \\
\hline & $\begin{array}{l}\mathrm{R}^{2}=0.53 \\
(\mathrm{P}=0.00002)\end{array}$ & & $\begin{array}{l}\mathrm{R}^{2}=0.43 \\
(\mathrm{P}=0.0003)\end{array}$ & $\begin{array}{l}\mathrm{R}^{2}=0.69 \\
(\mathrm{P}=0000001)\end{array}$ & & $\mathrm{R}^{2}=0.50$ \\
\hline & $\begin{array}{l}\chi=16.92 \\
(\mathrm{P}=0.00004)\end{array}$ & & $\begin{array}{l}\chi=10.89 \\
(\mathrm{P}=0.001)\end{array}$ & $\begin{array}{l}\chi=16.92 \\
(\mathrm{P}=0.00004)\end{array}$ & & $\begin{array}{l}\chi=10.89 \\
(\mathrm{P}=0.001)\end{array}$ \\
\hline 95 & 2.22 & 74 & 79 & 2.22 & 74 & 79 \\
\hline 90 & 3.35 & 63 & 63 & 3.35 & 63 & 63 \\
\hline 80 & 5.04 & 53 & 49 & 5.04 & 53 & 49 \\
\hline 50 & 9.55 & 39 & 32 & 9.55 & 39 & 32 \\
\hline 25 & 15.43 & 30 & 23 & 15.43 & 30 & 23 \\
\hline
\end{tabular}

explained by the relationship between trout density and mean $\operatorname{dip} \mathrm{ANC}_{\mathrm{D}}$ (Table 5).

Mean CL values were calculated from the dip water sample data at each of the 26 study sites using the episodically revised $\mathrm{ANC}_{\mathrm{CRIT}}$ value of $39 \mu \mathrm{eq} \mathrm{I}^{-1}$ and the original $0 \mu \mathrm{eq} \mathrm{l}^{-1} \mathrm{ANC}_{\mathrm{CRIT}}$ values. A comparison was then made between the two $\mathrm{CL}_{\mathrm{EX}}$ values, as an indicator of biological damage and the actual trout status at all sites. Two levels of trout status were used. The first was a presence/ absence classification and the second a sustainable classification, defined as the presence of at least one underyearling and one yearling trout per $100 \mathrm{~m}^{2}$. This sustainable classification provides evidence for potential spawning and recruitment, life stages most vulnerable to acidification. A higher percentage ( $92 \%$ for presence/ absence status and $88 \%$ for sustainable status) of matches between trout status and the $\mathrm{CL}_{\mathrm{EX}}$ values was obtained when an $\mathrm{ANC}_{\text {CRIT }}$ value of $39 \mu \mathrm{eq} \mathrm{l}^{-1}$ was used in the CL equation. This was compared to the lower percentage (85\% for presence/absence status and $81 \%$ for sustainable status) of matches when an $\mathrm{ANC}_{\text {CRIT }}$ value of $0 \mu \mathrm{eq}^{-1}$ was used.

\section{Discussion}

Water chemistry, particularly the acid-base variables, was the primary influential factor on the density and status of salmonid populations as was concluded similarly by Hesthagen et al. (1999) for brown trout populations in Norwegian streams. Land use, particularly the presence/ absence of coniferous/moorland was a secondary influential factor and habitat variables such as water flow, substrate and cover were also influential to a certain degree.

The choice of ANC or $\mathrm{pH}$, as a reflection of the acid-base status, has given rise to some debate (Ormerod, 1995). Harriman et al. (1990b) suggested that the critical point for trout viability was when the frequency of $\mathrm{pH}<5.5$ exceeded about $30 \%$ of the time but they did not evaluate the use of ANC. In this study, ANC explained more variance in brown trout density than $\mathrm{pH}$ and was, therefore, considered a suitable biological surrogate for the chosen indicator species, brown trout, in Scottish streams.

These results indicate that, by incorporating some measure of episodicity, an $\mathrm{ANC}_{\mathrm{CRIT}}$ value of $39 \mu \mathrm{eq} \mathrm{l}^{-1}$, based on a $50 \%$ probability of the occurrence of brown trout in streams, would be a more suitable biological surrogate to be incorporated into the $\mathrm{CL}$ equation. This higher $\mathrm{ANC}_{\mathrm{CRIT}}$ value also improved the relationship between trout status and $\mathrm{CL}_{\mathrm{EX}}$. This was largely as a result of the coniferous sites providing a better match between trout status and the revised $\mathrm{CL}_{\mathrm{EX}}$ value.

Henriksen et al. (1995) suggested a variable $\mathrm{ANC}_{\mathrm{CRIT}}$ as a function of the acidifying deposition to the lake, nearing $0 \mu \mathrm{eql}^{-1}$ at low deposition and increasing to higher values at higher deposition. As aluminium is known to be toxic to aquatic organisms (Muniz and Leivistad, 1980), McCartney et al. (2003) suggested a variable $\mathrm{ANC}_{\mathrm{CRIT}}$ between $0 \mu$ eq $\mathrm{l}^{-1}$ and $40 \mu \mathrm{eq} \mathrm{l}^{-1}$, as a function of the AL-L concentration and the extent to which DOC will reduce the potential toxicity of AL-L. Their proposed range of $\mathrm{ANC}_{\mathrm{CRIT}}$ values for brown trout streams are: 
$\mathrm{ANC}_{\mathrm{CRIT}}=10 \mu \mathrm{eq} \mathrm{l}^{-1}$ at $<30 \mu \mathrm{g} \mathrm{l}^{-1} \mathrm{Al}-\mathrm{L}$;

$\mathrm{ANC}_{\mathrm{CRIT}}=25 \mu \mathrm{eq} \mathrm{l}^{-1}$ at $30-100 \mu \mathrm{g} \mathrm{l}^{-1} \mathrm{Al}-\mathrm{L}$;

$\mathrm{ANC}_{\mathrm{CRIT}}=40 \mu \mathrm{eq} \mathrm{l}^{-1}$ at $>100 \mu \mathrm{g} \mathrm{l}^{-1} \mathrm{Al}-\mathrm{L}$.

Five of the study sites (CHF, BLF, CEF, B7F and B11F) had mean Al-L concentrations between 30 and $100 \mu \mathrm{gl}^{-1}$ (Table 1), which, according to the proposed $\mathrm{ANC}_{\mathrm{CRIT}}$ ranges above, necessitated using an $\mathrm{ANC}_{\text {CRIT }}$ value of $25 \mu \mathrm{eq} \mathrm{l}^{-1}$ to ensure trout survival at these sites. Four of these sites (BLF, $\mathrm{CEF}, \mathrm{B} 7 \mathrm{~F}$ and $\mathrm{B} 11 \mathrm{~F}$ ) had no match between the $\mathrm{CL}_{\mathrm{EX}}$ value, using an $\mathrm{ANC}_{\mathrm{CRIT}}$ value of $0 \mu \mathrm{eq} \mathrm{l}^{-1}$, and brown trout status ie brown trout were neither present or sustainable but the CL was not exceeded. However, using the episodically revised $\mathrm{ANC}_{\mathrm{CRIT}}$ value of $39 \mu \mathrm{eq} \mathrm{l}^{-1}$, a match between $\mathrm{CL}_{\mathrm{EX}}$ and brown trout status at $\mathrm{CEF}, \mathrm{B} 7 \mathrm{~F}$ and $\mathrm{B} 11 \mathrm{~F}$ was obtained. All five sites were located within forested catchments reflecting the higher Al-L concentrations often associated with afforestation and the necessity for higher $\mathrm{ANC}_{\mathrm{CRIT}}$ values to sustain trout populations in such vulnerable locations.

The CL concept was originally designed to provide the most cost effective and scientifically based method of targeting emission reductions of sulphur (and later nitrogen). It is also recognised to be a relatively blunt tool for addressing site-specific issues because any selected ANC value can represent a diverse mix of biologically important components, such as acidity, Al-L (negative impact) and DOC (positive impact). A reduction in the non-marine sulphate, $\mathrm{H}^{+}$and Al-L concentrations in Scottish streams has been observed by Harriman et al. (2001), who also concluded that biological recovery, evident from data in some lochs, is not readily apparent from stream data probably due to their more episodic nature. Despite the strong evidence for chemical recovery, most CL models have no means of predicting the time scale of biological recovery. As ANC increases in streams and lochs, the probability of occurrence of viable trout populations will increase. However, if a move towards a more precautionary approach is contemplated, to satisfy sustainability or conservation requirements, then a higher $\mathrm{ANC}_{\mathrm{CRIT}}$ value may be necessary, resulting in more stringent requirements for emission reductions. The use of an episodically modified $\mathrm{ANC}_{\mathrm{CRIT}}$ value of $39 \mu \mathrm{eq} \mathrm{l}^{-1}$ should, therefore, protect brown trout populations in streams at a sustainable level at sites where CLs are not exceeded. In conclusion, it must be stressed that these data were derived from studies at 26 stream sites only and that the uncertainties may increase if biologically important components such as DOC and Al-L have greater variability on a regional or national basis.

\section{Acknowledgements}

The authors are grateful to NERC who partly funded this project and to all their FL colleagues for their valued contributions both int he field and laboratory.

\section{References}

Bain, M.B., Finn, J.T. and Booke, H.E., 1985. Quantifying stream substrate for habitat analysis studies. N. Amer. J. Fisheries Manage., 5, 499-506.

Brewin, P.A., Chaud, F., Masters, Z., Rothfritz, H. and Ormerod, S.J., 1998. Invertebrate biology: towards MEDUSA (models of ecosystem dynamics under stream acidification). ENSIS Publishing, London, UK. 29pp.

Bridcut, E.E., 2000 A study of terrestrial and aerial macroinvertebrates on river banks and their contribution to drifting fauna and salmonid diets in a Scottish catchment. Hydrobiologia, 427, 83-100

Cantrell, K.J., Serkiz, S.M. and Perdue, E.M., 1990. Evaluation of acid neutralizing capacity data for solutions containing natural organic acids. Geochim. Cosmochim. Acta, 54, 1247-1254.

Friberg, N., Rebsdorf, A. and Larsen, S.E., 1998. Effects of afforestation on acidity and invertebrates in Danish streams and implications for freshwater communities in Denmark. Water Air Soil Pollut., 101, 235-256.

Gibson, R.J., Stansbury, D.E., Whalen, R.R. and Hillier, K.G., 1993. Relative habitat use, and inter-specific and intra-specific competition of brook trout (Salvelinus fontinalis) and juvenile Atlantic salmon (Salmo salar) in some Newfoundland rivers. In: Production of juvenile Atlantic salmon, Salmo salar, in natural waters, R.J. Gibson and R.E. Cutting (Eds.). Can. Spec. Publ. Fisheries Aquat. Sci., 118, 53-69.

Harriman, R.and Morrison, B.R.S., 1982. Ecology of streams draining forested and nonforested catchmnets in an area of central Scotland subject to acid precipitation. Hydrobiologia, 88, 251-263.

Harriman, R. and Christie, A.E.G., 1993. Evaluation of the steadystate water chemistry method for surface waters. In: Critical loads: concept and applications, M. Hornung and R.A. Skeffington (Eds.). Institute of Terrestrial Ecology, UK. 103-108.

Harriman, R. and Taylor, E.M., 1999. Acid neutralising capacity $(A N C)$ and alkalinity (ALK): Concepts and measurement. SNIFFER Report SR(99)06F. 14pp.Harriman, R., Morrison, B.R.S., Caines, L.A., Collen, P. and Watt, A.W., 1987. Longterm changes in fish populations of acid streams in Galloway, South-West Scotland. Water Air. Soil. Pollut., 32, 89-112.

Harriman, R., Gillespie, E., King, D., Watt, A.W., Christie, A.E.G., Cowan, A.A. and Edwards, T., 1990a. Short-term ionic responses as indicators of hydrochemical processes in the Allt a Mharcaidh catchment, western Cairngorms, Scotland. J. Hydrol., 116, 267285.

Harriman, R., Gillespie, E. and Morrison, B.R.S., 1990b. Factors affecting fish survival in Scottish catchments. In: The Surface Waters Acidification Programme, B.J. Mason (Ed.) Cambridge University Press, UK. 343-355.

Harriman, R., Watt, A.W., Christie, A.E.G., Collen, P., Moore, D.W., McCartney, A.G., Taylor, E.M. and Watson, J., 2001. Interpretation of trends in acidic deposition and surface water chemistry in Scotland during the past three decades. Hydrol. Earth Syst. Sci., 5, 407-420. 
Heggenes, J., Bagliniere, J.L. and Cunjak, R.A., 1999. Spatial niche variability for young Atlantic salmon (Salmo salar) and brown trout (S. trutta) in heterogeneous streams. Ecol. Freshwater Fish, 8, 1-21.

Henriksen, A., Posch, M., Hutlberg, H. and Lien, L., 1995. Critical Loads of acidity for surface waters- Can the ANC limit be considered variable? Water Air Soil Pollut., 85, 2419-2425.

Henriksen, A., Skjelvale, B.L., Mannio, J., Wilander, A., Harriman, R., Curtis, C., Jensen, J.P., Fjeld, E. and Moiseenko, T., 1998. Northern European Lake Survey, 1995. Ambio, 27, 80-91.

Hesthagen, T., Heggenes, J., Larsen, B.M., Berger, H.M. and Forseth, T., 1999. Effects of water chemistry and habitat on the density of young brown trout Salmo trutta in acidic streams. Water Air Soil Pollut., 112, 85-106.

Hill, M.O., 1979. TWINSPAN - a fortran program for arranging multivariate data in an ordered two-way table by classification of the individuals and attributes. Ecology and Systematics. Cornell University, Ithaca, NY 14850, USA.

Lacroix, G.L., Gordon, D.J. and Johnston, D.J., 1985. Effects of low environmental $\mathrm{pH}$ on the survival, growth, and ionic composition of postemergent Atlantic salmon (Salmo salar). Can. J. Fisheries Aquat. Sci., 42, 768-775.

Lien, L., Raddum, G.G. and Fjellheim, A., 1992. Critical Loads of acidity to freshwater- fish and invertebrates. In: "Naturens Talegrenser" no.23. Norwegian Institute for Water Research, Oslo, Norway.
McCartney, A.G., Harriman, R., Watt, A.W., Moore, D.W., Taylor, E.M., Collen, P. and Keay, E.J., 2003. Long-term trends in pH, aluminium and dissolved organic carbon in Scottish fresh waters: implications for brown trout (Salmo trutta) survival. Sci. Total Envir, 314-316, 233-254.

Morrison, B.R.S., 1998. Forests and Fisheries. In: The Institute of Fisheries Managment $27^{\text {th }}$ Annual Study Course, York, 1996, S. Axford and G. Perrson (Eds.).

Muniz, I.P. and Leivstad, H., 1980. Acidification-effects on freshwater fish. In: Proceedings of the International Conference of Ecological Impacts of Acid Precipitation. March 11-14 th 1980, Sandfjord, Norway, D. Drablos and A. Tollan (Eds.). 222-223.

Nilsson, J. and Grennfelt, P., 1988. Critical loads for sulphur and nitrogen. UNECE/Nordic Council workshop report, Skokloster, Sweden, Nordic Council of Minister: Copenhagen, Denmark.

Ormerod, S.J., 1995. Modelling biological responses, present and future. In: CLAG Critical loads of acid deposition for United Kingdom Freshwaters, Institute of Terrestrial Ecology Edinburgh, UK. 47-57.

Peterson, R. H., Daye, P.G. and Metcalfe, J.L., 1980. Inhibition of Atlantic salmon (Salmo salar) hatching at low pH. Can. J. Fisheries Aquat. Sci., 37, 770-774.

Zippin, C. 1956. An evaluation of the removal method of estimating animal populations. Biometrics 12, 163-189. 